JIIP: Jurnal IImiah IImu Pemerintahan

Volume 5, Nomor 2, Tahun 2020

DOI: 0.14710/jiip.v5i2.8146

\title{
Kemenangan Hattrick: Strategi Keterpilihan Een Rusmiyati dalam Pemilu Legislatif 2019 di Kota Cirebon
}

\author{
Akhmad Muzadi ${ }^{1}$ \& Fitriyah ${ }^{2}$ \\ 1,2 Magister Ilmu Politik, Universitas Diponegoro
}

\section{INTISAR|}

Penelitian ini di latar belakangi oleh kemenangan Een Rusmiyati di pemilu legislatif yang kembali terpilih untuk ketiga kalinya sebagai anggota DPRD perempuan dari Partai Hanura, salah satu partai kecil di Kota Cirebon. Penelitian ini menggunakan teori representasi politik dari Vieira dan Runciman dan strategi politik Sheth dan Frazier sebagai alat untuk menjelaskan keterpilihan petahana Een Rusmiyati dalam Pemilu 2019. Adapun untuk metode penelitian menggunakan pendekatan kualitatif dengan teknik pengumpulan data berupa wawancara dan dokumentasi. Temuan penelitian menunjukkan Een Rusmiyati merupakan satu-satunya calon anggota legislatif yang terpilih dari Partai Hanura, yang mampu merawat konstituen sehingga bisa mengantarkan dirinya terpilih di pemilu berulang kali. Tugas perawatan konstituen berjalan efektif karena dirinya dibantu oleh tim sukses yang loyal, yang diketuai oleh adik laki-lakinya.

\section{KATA KUNCI}

keterpilihan; pemilu legislatif; perempuan; petahana; strategi politik

\section{Pendahuluan}

enelitian ini di latar belakangi oleh kemenangan hattrict Een Rusmiyati di pemilu legislatif, ia kembali terpilih untuk ketiga kalinya sebagai anggota DPRD perempuan dari Partai Hanura, partai kecil di Kota Cirebon. Sukses Een tidak lepas dari digunakannya sistem pemilu proposional terbuka dengan suara terbanyak, yang berlaku sejak Pemilu 2009. Sistem ini memungkinkan pemilih mencoblos nama caleg di surat suara yang dipilihnya, daripada mencoblos tanda gambar partai. Sistem ini mendorong pengenalan dan kedekatan calon legislatif terhadap pemilih di daerah pemilihannya mulai dibangun jauh hari sebelum masa pemilu, setelah terpilih konstituennya perlu dirawat untuk keterpilihan di pemilu berikutnya.

Pengalaman Een Rusmiyati menunjukkan ia diuntungkan oleh sistem pemilu proporsional daftar calon terbuka. Modalitas yang dimiliki Een Rusmiyati mengantarkannya terpilih di Pemilu 2009, selanjutnya ia mampu merawat

Korespodensi:

Magister Ilmu Administrasi, Universitas Diponegoro, Jalan Professor Soedarto SH, Tembalang, Kec. Tembalang, Kota Semarang, Jawa Tengah 50139.

Email: amuzadi19@gmail.com. 
konstituennya untuk memertahankan posisinya. Modalitas Een Rusmiyati berperan penting dalam keterpilihannya bisa dilihat dari posisi partai pengusung Een Rusmiyati, yaitu Partai Hanura yang di Kota Cirebon termasuk partai kecil. Di Pemilu 2019 Partai Hanura hanya dapat satu kursi milik Een Rusmiyati, jumlah kursi turun dibanding di Pemilu 2009 dan Pemilu 2014 dengan tiga kursi. Artikel ini bermaksud menjelaskan strategi Een Rusmiyati dalam merawat konstituen pada saat pemilu dan pasca pemilu menggunakan teori representasi politik dari Vieira dan Runciman dan teori strategi politik Sheth dan Frazier, teori-teori ini dinilai mampu untuk menjelaskan kasus Een Rusmiyati yang berhasil hattrict menang tiga kali berturut-turut. Data yang digunakan dibatasi pada Pemilu 2019 yang mengantarkan Een sebagai satu-satunya wakil Partai Hanura.

Kasus Een Rusmiyati menarik diteliti karena ia perempuan dan diusung oleh partai kecil, tetapi mampu bertahan tiga periode. Sebagai gambaran, jumlah kursi DPRD Kota Cirebon sebanyak 35 kursi sejak 2014 , sebelumnya hanya 30 kursi. Dari jumlah 35 kursi tersebut pada Pemilu 2019 terpilih sebanyak 10 orang (28,87\%) anggota legislatif perempuan dan empat di antaranya adalah petahana termasuk Een Rusmiyati. Pada Pemilu 2014 jumlah perempuan terpilih sembilan orang, artinya lima petahana perempuan gugur. Dari petahana perempuan yang kembali terpilih di Pemilu 2019 hanya Een Rusmiyati yang hattrict. Secara umum perempuan yang ingin masuk dalam dunia politik (parlemen) menemukan sejumlah hambatan struktural fungsional yang dibentuk oleh hubungan sosial dan politik dalam suatu masyarakat (Azis, 2013). Artikel ini akan menjelaskan strategi kemenangan Een Rusmiyati pada Pemilu 2019 di Kota Cirebon, perempuan selama ini dianggap sebagai "orang lemah" dalam politik. Namun, hal tersebut dibantahkan oleh keterpilihan Een Rusmiyati dalam tiga periode berturutturut.

Studi sebelumnya memang menunjukkan peluang petahana menang lebih besar. Studi Ban, Llaudet, \& Snyder Jr (2016: 155) misalnya, mengidentifikasi sejumlah keuntungan yang didapatkan oleh calon legislatif petahana, yaitu: (1) petahana mungkin memiliki "kualitas" lebih tinggi daripada kandidat lain, sebaliknya penantang yang bersaing melawan petahana mungkin memiliki "kualitas" yang lebih rendah, dan (2) dengan mememegang jabatan, menyediakan sumber daya bagi petahana yang dapat mereka gunakan untuk memenangkan suara. Akan tetapi, melihat kasus di Kota Cirebon tidak semua petahana terpilih kembali, dalam konteks ini petahana akan tetap bergantung pada strategi yang digunakan dalam mempertahankan kekuasannya dan mobilisasi sumber daya (basis pendukung) yang selama ini terjalin melalui jabatannya di DPRD (fungsi representasi politik).

Studi berikutnya dari Aswagati (2019) dengan judul “Merawat Konstituen Politik: Studi Kasus Calon Legislatif Petahana Partai Demokrat Daerah Pemilihan I Jawa Tengah Periode Pemilihan Legislatif 2009 dan 2014". Fokus penelitian tentang strategi petahana merawat konstituen, studi oleh Caleg Partai Demokrat: Agus Hermanto (DPR), A.S. Sukawijaya (DPR Provinsi) dan Roh Prihati (DPRD Kota Semarang), yang diteliti anggota DPR/DPRD dua periode secara berturut-turut. Tipe penelitiannya kualitatif deskriptif. Temuan, para calon menggunakan tim pemenangan yang solid, jaringan politik yang kuat dengan menggandeng organisasi-organisasi massa, pemanfaatan jabatan sebagai petahana, dan membangun komunikasi dengan baik terhadap masyarakat. 
Studi yang lain oleh Ayu, Indriani, \& Azhar (2019) dengan judul "Strategi Politik Calon Anggota DPRD Perempuan Petahana Pada Pemilu Serentak Tahun 2019 Di Provinsi Bali". Fokus penelitian tentang strategi politik anggota Dewan Perwakilan Rakyat Daerah perempuan petahana dalam Pemilihan Serentak 2019 di Bali, menggunakan teori strategi ofensif dan defensif dari Peter Schroder tipe penelitian kualitatif deskriptif. Temuan, calon menggunakan strategi ofensif untuk memperluas jumlah pemilih dengan melakukan turba (turun langsung ke bawah), dan strategi defensif untuk mempertahankan jumlah pemilih pemilu sebelumnya agar konstituen kembali memilih dengan melakukan silaturahmi.

Studi dari Setyo (2016) dengan judul "Model Kampanye Politik Berbasis Silaturahim Bagi Calon Anggota Dewan Incumbent dalam Pemilu Legislatif tahun 2014". Fokus penelitian tentang efektivitas kampanye politik berbasis silaturahim oleh calon inkumben dalam pemilu legislatif tahun 2014, menggunakan teori Larson tentang model perkembangan lima tahap fungsional. Tipe penelitiannya kualitatif deskriptif. Temuannya, model kampanye politik berbasis silaturahim memiliki efektivitas yang sangat tinggi karena memberikan eksistensi calon anggota legislatif dan lebih dekat kepada konstituen.

Studi dari Adlin \& Triawang (2015) dengan judul "Strategi Komunikasi Politik Petahana Dedi Humadi dalam Pemilihan Umum Legislatif Anggota Dewan Perwakilan Rakyat Daerah Kabupaten Rokan Hilir Tahun 2014". Fokus penelitian tentang strategi komunikasi yang digunakan sehingga kembali terpilih secara tiga kali berturut-turut, menggunakan teori Teori strategi positioning atau strategi untuk merebut dan mempertahankan pasar, dengan beberapa variabel yaitu kampanye politik, retorika politik, public relation politik, dan media politik. Tipe penelitian kualitatif. Temuan, calon menggunakan kampanye politik tatap muka, memberi bantuan sosial dan berdiskusi dengan masyarakat. Menggunakan retorika politik yang disiapkan dan dibacakan oleh Dedi Humadi sehingga mudah dimengerti oleh masyarakat. Melakukan public relation politik dengan berhubungan baik terhadap masyarakat, aktif mengikuti kegiatan sosial dan tidak ada jarak kepada masyarakat. Media yang digunakan adalah spanduk, baleho, kalender dan stiker.

Studi selanjutnya dari Veronika (2013) dengan judul "Pemasaran Politik Legislatif Petahana dalam Memenangkan Pemilu Anggota DPRD Kota Kupang Provinsi Nusa Tenggara Timur Tahun 2009 (Kajian Strategi Politik dan Bauran Politik)". Fokus penelitian tentang strategi pemasaran politik yang digunakan calon legislatif petahana, menggunakan teori strategi pemasaran politik meliputi segmentating, targeting, positioning dan bauran produk politik. Tipe penelitiannya kualitatif deskriptif. Temuan, calon petahana melakukan perawatan pemilihnya dengan lebih fokus pada wilayah yang menang mayoritas tanpa memandang unsur agama dan etnis, petahana konsisten terhadap pemenuhan dasar masyarakat selama menjabat dan konsisten terhadap janji politiknya.

Studi lainnya dari Ning, Erviantono, \& Azhar (2016) dengan judul "Strategi Incumbent Mempertahankan Suara Pasca Pindah Partai Pada Pemilu Legislatif Kota Denpasar Tahun 2014". Fokus penelitian tentang strategi inkumben dalam mempertahankan suara dalam pemilu legislatif ketika berpindah partai (Partai Golkar menjadi Partai Nasdem), menggunakan teori strategi ofensif dan defensif dari Peter 
Schroder. Tipe penelitiannya kualitatif deskriptif. Temuan, calon menggunakan strategi ofensif melalui pemasangan baliho untuk memperkenalkan dirinya sebagai anggota partai politik yang berbeda, bekerjasama dengan organisasi dan karang taruna desa. Strategi defensif dengan melakukan perawatan konstituen politiknya pada daerah kelahiran dengan berbasiskan tradisi yaitu memukur dan mesangih.

Studi terakhir dari Nikmah (2015) dengan judul "Kandidat Petahana DPRD Kota Surabaya Pada Pemilu Legislatif 2014 (Studi Deskriptif Caleg Terpilih Melalui Partai Kebangkitan Bangsa)". Fokus penelitian tentang faktor yang melatarbelakangi kandidat petahana maju kembali serta upaya-upaya yang dapat dilakukan oleh kandidat dalam mempertahankan kekuasaannya, menggunakan teori Schlesinger dengan tiga kategori ambisi politik, (1) politisi agresif, (2) politisi statis dan (3) politisi progresif. Tipe penelitian kualitatif deskriptif. Temuan, tiga faktor yang melatarbelakangi kandidat petahana maju kembali yaitu faktor keinginan sendiri, faktor konstituen serta beberapa faktor pendukung lain diluar dari hal tersebut seperti kinerja dan track record.

Berdasarkan review atas penelitian terdahulu di atas, maka dapat dijelaskan bahwa perbedaan antara penelitian terdahulu dengan yang akan diteliti adalah kebaruan dari data dan teori yang digunakan, kebanyakan dari penelitian terdahulu yang penulis inventarisasi menjelaskan strategi petahana dalam pemenangan pemilu dengan menggunakan teori strategi dari Peter Schroder (Bandiyah et al dan Erviantono et al), teori Schlesinger tiga kategori ambisi politik (Nurun Hikmah), model perkembangan lima tahap fungsional dari Larson (Bono Setyo), teori strategi pemasaran politik (Veronika Ina Assan Boro), teori Strategi Positioning (Arief Triawang), dan teori strategi merawat konstituen politik (Swasti Aswagati).

Studi yang dilakukan oleh Nurun Hikmah, Arief Triawang, Sawasti Aswagati, Erviantono et al. dan Bono Setyo ialah calon anggota legislatif petahana laki-laki yang maju kembali dalam pemilihan selanjutnya. Sementara studi yang dilakukan oleh Bandiyah et al., dan Veronika Ina Assan Boro menjelaskan tentang calon anggota legislatif perempuan dengan perbedaan pada teori yang digunakan, seperti studi dari Bandiyah et al. menggunakan teori Peter Schorder dalam menjelaskan strategi ofensif dan defensif yang dilakukan oleh calon anggota legislatif petahana perempuan dalam mempertahankan kursi kekuasaanya dan studi yang dilakukan oleh Veronika Ina Assan Boro menjelaskan strategi pemasaran politik yang dilakukan oleh calon anggota legislatif perempuan petahana dalam mempertahankan kekuasaanya dengan menarget pemilih tanpa memandang agama dan etnis kemudian kandidat mampu merawat konstituennya dengan pemenuhan dasar kebutuhan dan konsisten terhadap janji kampanye.

Didalam penelitian ini penulis fokus pada studi petahana perempuan dalam Pemilu tingkat kota dan berasal dari partai politik hanura caleg terpilih satu-satunya. Teori yang digunakan dalam menjelaskan pola-pola hubungan antara wakil-konstituen menggunakan teori representasi dari Vieira dan Runciman yang kemudian dapat memberikan modal kepada caleg perempuan petahana sehingga dapat menggunakan strategi yang sudah ditentukannya untuk pemilihan berikutnya menggunakan teori strategi dari Jagdish N. Sheth dan Gary L. Frazier.

Penelitian ini menggunakan pendekatan kualitatif Creswell (2014: 4). Penentuan informan dalam penelitian ini dilakukan secara purposive sampling, sebagai informan adalah Een Rusmiyati, ketua tim sukses, dan lima orang konstituen. Data yang 
digunakan terdiri atas data primer yang diperoleh melalui wawancara dengan para informan dan data sekunder hasil pemilu yang diperoleh dari KPU Cirebon dan hasil penelusuran website KPU. Analisis data dalam penelitian dilakukan selama di lapangan, dan setelah selesai di lapangan. Langkah analisis data yaitu reduksi data, penyajian data, penarikan kesimpulan dan verifikasi (Sugiyono, 2013: 245).

\section{Representasi dan Strategi Politik: Sebuah Landasan Teoritis}

Strategi politik didefinisikan oleh Firmanzah (2008: 244) sebagai "Semua cara, metode dan teknik yang digunakan untuk dapat mencapai tujuan-tujuan politik yang telah dirumuskan". Menurut Osuagwu (2008: 797) pada sebagian besar negara demokrasi di dunia para politisi dan partai politik mencari teknik pemasaran yang taktis dan strategis untuk membuat diri mereka relevan dimata pemilih dan mendapatkan dukungan suara dalam pemilu atau kembali dipilih pada pemilu berikutnya, para politisi dan partai politik menyadari perlunya mencocokkan penawaran politik mereka dengan nilai-nilai inti audiens yang relevan. Maka, strategi keterpilihan petahana adalah cara, metode dan teknik yang digunakan calon petahana dalam mengikuti kontestasi pemilu melalui jabatan sebagai wakil rakyat guna terpilih kembali dengan mempertimbangkan aspek nilai-nilai inti audiens yang relevan.

Sheth \& Frazier (1982: 17) menjelaskan strategi yang dipakai oleh kandidat atau partai politik dalam memperebutkan atau mempertahankan suara bisa dilakukan melalui empat proses, yaitu (1) reinforcement process (proses penguatan), yakni menjaga orang dalam sikap positif melalui memperkuat perilaku, memperkuat sikap atau memperkuat keduanya; (2) inducement process (proses bujukan), yakni mengubah perilaku orang dalam sikap negatif menjadi positif; (3) rationalization process (proses rasionalisasi), yakni menghasilkan perubahan sikap perilaku yang lebih konsisten; dan (4) confrontation process (proses konfrontasi), yakni mengubah perilaku sosial dalam opini publik dengan menggunakan basis kekuatan yang dimiliki untuk mengubah perilaku sosial secara masif. Setiap elemen dapat dijadikan sebuah strategi untuk memperebutkan atau mempertahankan suara didalam pemilu.

Kepersertaan petahana diakui dalam pemilu lebih unggul dibanding pendatang baru, sebagai petahana ia menguasai sumber daya yang dapat mereka gunakan untuk memenangkan suara (Ban et al., 2016: 155). Petahana, melalui fungsi representasi selama menjabat di lembaga perwakilan punya ruang untuk memelihara basis suaranya. Aktivitas reses per-empat bulan sekali memberi kesempatan anggota DPRD pulang ke dapilnya, bertemu konstituen, dan melakukan fungsi representasi politik. Artinya, representasi politik menjadi sebuah dasar pemaknaan bahwa orang yang merasa dirinya diwakili bisa memberikan banyak permintaan kepada wakilnya agar dapat diteruskan ke lembaga perwakilan. Fungsi representasi politik ini bila dikelola dengan baik akan memerkuat basis dukungan yang berguna saat pemilu.

Saward (2006: 6) mejelaskan bahwa "representasi dalam politik setidaknya dua arah: yang diwakili berperan dalam memilih perwakilan dan perwakilan 'memilih' konstituen mereka dalam arti menggambarkan mereka atau membingkai mereka secara khusus. Fungsi representasi politik dalam studi ini dianalisis menggunakan teori representasi politik dari Vieira \& Runciman (2008: 20) yang menjelaskan tiga bentuk representasi politik, yaitu: (1) pictorial representation, mereka yang dipilih untuk 
mewakili harus menyerupai yang diwakilinya; (2) theatrical representation, wakil yang terpilih harus menafsirkan, berbicara dan bertindak untuk pihak yang diwakilinya, dan (3). juridical representation, wakil yang terpilih harus bertindak atas nama yang diwakilinya dengan persetujuan demi kepentingan bersama.

Penelitian ini menggunakan teori representasi politik dari Vieira \& Runciman (2008) serta strategi politik Sheth \& Frazier (1982) sebagai alat untuk menjelaskan keterpilihan petahana Een Rusmiyati dalam Pemilu 2019. Kerangka pemikirannya dapat dilihat dari gambar berikut.

Bagan 1 Kerangka Pemikiran Strategi Keterpilihan Een Rusmiyati

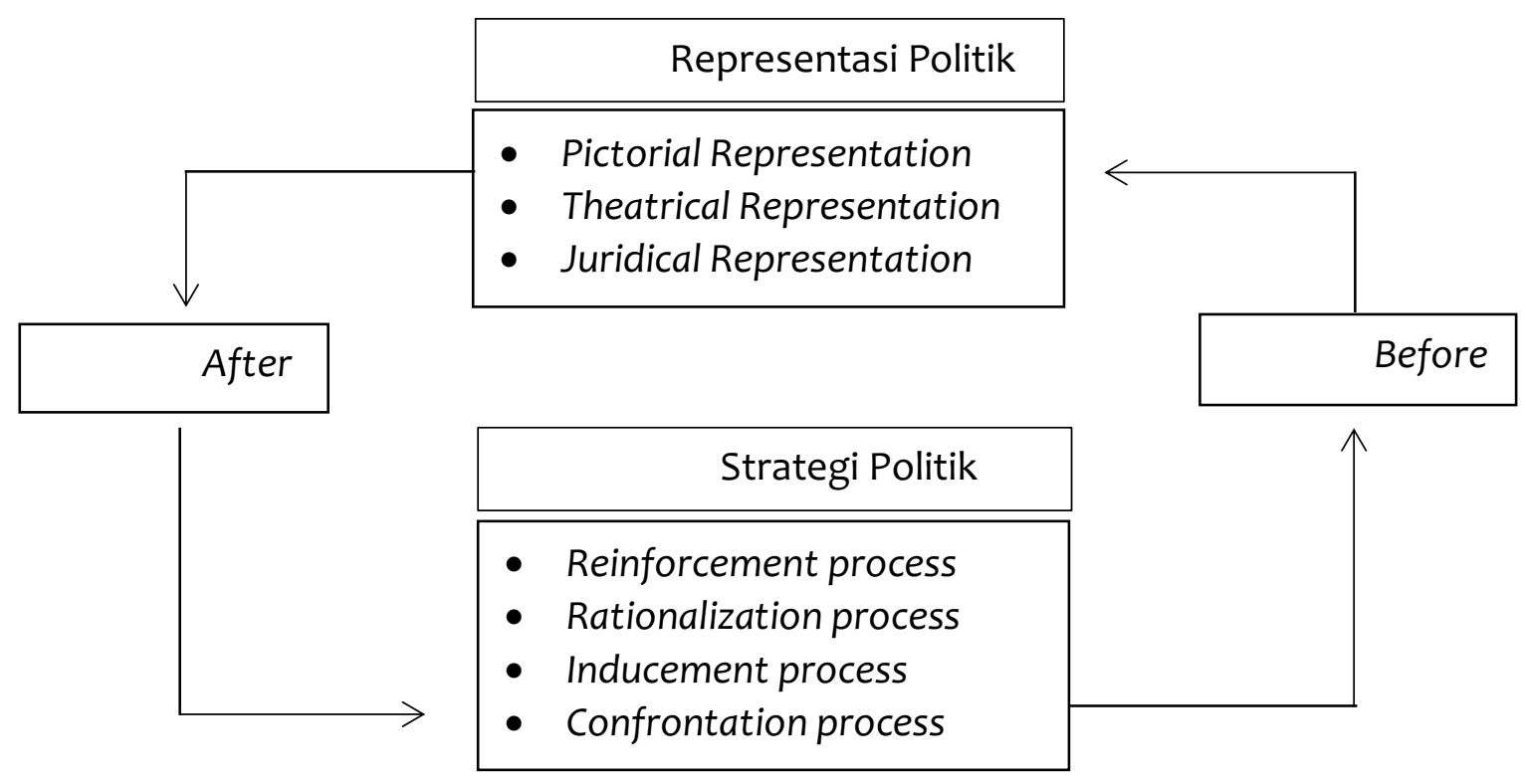

Sumber: diolah oleh peneliti, 2019

\section{Een Rusmiyati, Anggota DPRD Kota Cirebon dari Partai Hanura}

Een Rusmiyati (dipanggil Een) lahir di Cirebon pada tanggal 5 Juni 1971 dengan memiliki riwayat pendidikan sekolah dasar di SDN Kedung Krisik Kota Cirebon, sekolah menengah pertama di SMPN 9 Kota Cirebon, sekolah menengah atas di SMA Cendrawasih Kota Cirebon dan melanjutkan ke perguruan tinggi swasta di YASMI Kota Cirebon. Pengalaman pekerjaan, bekerja di PT. Ropina Indah Jaya Posh Boy (Pashion) kemudian di PT. Kalbe Farma Cakson F, BA. Laggend Cosmetics dan BC. Inez Cosmetics. Pengalaman organisas di Partai Hanura, ketua Srikandi Partai Hanura Kota Cirebon, tahun 2014 menjadi Ketua Partai Hanura.

Een telah menjadi anggota dewan selama tiga periode berturut-turut dimulai pada tahun 2009, 2014 dan 2019. Een mempunyai banyak pengalaman selama menjadi anggota dewan, Een menceritakan bahwa dirinya tertarik menjadi anggota DPRD atas saran Wakil Walikota Cirebon kala itu. Berikut penuturannya, "Pada saat itu, Wakil Walikota Cirebon, Bapak Naryo menyarankan saya untuk menjadi seorang anggota 
dewan, ketika itu memang saya belum ada keinginan karena pada saat itu saya masih berorganisasi dan lain sebagainya" (wawancara, 08 Januari 2020)

Een juga menceritakan tentang mengapa dirinya akhirnya ikut dalam pemilihan legislatif untuk pertama kalinya, meskipun dorongan itu diakui awalnya berasal Wakil Walkota Cirebon. Menurutnya ada hal lain yang akhirnya membuat dirinya tergerak untuk menjadi anggota dewan, adalah aktivitasnya di ruang publik. Berikut ungkapannya, "Saya tertarik menjadi anggota dewan, karena pada saat itu saya juga sering mengadakan kegiatan, seperti mengikuti karang taruna, mengikuti organisasi Pemuda Pancasila dan lain sebagainya, sehingga saya ingin menjadi anggota dewan" (wawancara, 08 Januari 2020)

Een menjelaskan bahwa latar belakang keluarganya dari kalangan warga biasa, seperti yang dijelaskan oleh Een sebagai berikut, "Keluarga saya biasa-biasa saja ya, bahkan saya juga bukan terlahir dari seorang keluarga yang kaya, saya hanya terlahir dari keluarga yang miskin" (wawancara, 08 Januari 2020). Een menerangkan bahwa awal mencalonkan sebagai anggota dewan memang tidak mudah, diperlukan jaringan dan dukungan dari berbagai pihak, baik itu berasal dari keluarga maupun dari luar, seperti organisasi dan tim sukses yang dapat dijadikan sebagai perantara di dalam menjaring suara. Keterangan Een sebagai berikut:

Saya memupuk masyarakat dari awal, saya juga punya kader yang militan yang dapat membantu saya, karena memang saya tidak bisa bekerja sendiri, setiap kelurahan saya memiliki satu orang perwakilan saya baik itu kader maupun keluarga saya sendiri untuk ditempatkan (wawancara, 08 Januari 2020)

Pada periode berikutnya tumbuh keinginan yang begitu kuat dari seorang Een sehingga ia kembali maju untuk Pemilu tahun 2014 dan 2019, berikut pernyatannya: Untuk memajukan wilayah daerah pemilihan saya yaitu kecamatan Harjamukti Kota Cirebon, pembenahan infrastruktur juga harus dilakukan khususnya pada daerah pemilihan saya karena memang berada pada daerah perbatasan dan umumnya pembangunan Kota Cirebon (wawancara, 08 Januari 2020)

Pengalamannya yang luas di dalam berorganisasi sosial memberikan kesempatan bagi Een untuk menambah pengalaman di dalam berorganisasi politik, ia menjadi anggota Partai Hanura. Een menjadi satu-satunya anggota dewan yang berasal dari Partai Hanura pada Pemilu tahun 2019. Berikut penuturannya, "Ya pengalaman saya selama berada di Partai Hanura, saya pernah menjadi ketua Srikandi Partai Hanura Kota Cirebon dan pada tahun 2014 saya menjadi ketua Partai Hanura kota Cirebon hingga sekarang" (wawancara, 08 Januari 2020)

Selama tiga periode menjadi anggota dewan tentu hal ini memberikan situasi yang berbeda-beda, tidak terkecuali ialah tim sukses yang bekerja dibalik keterpilihan dari Een Rusmiyati. Berikut ungkapannya, "Untuk tim sukses selalu sama dari awal sampai kemarin, tim sukses itu tim yang militan dan setia kepada saya, kemudian ada beberapa tambahan saja dari tim tersebut" (wawancara, 08 Januari 2020)

Tim sukses merupakan tim yang dapat bekerja dalam mensukseskan calon anggota legislatif hingga menjadi anggota dewan. Een menjelaskan bahwa dirinya memilih adik kandungnya sebagai pemimpin didalam tim suksesnya, tentu hal ini sangat menarik karena peranan keluarga sangat membantu Een untuk menjadi seorang anggota dewan, adik kandung Een bernama Isnen dengan nama panggilan Iwo, berikut ini penjelasan dari Iwo ketua tim sukses dari Een: 
Hubungan saya dengan Ibu Een adalah adik kandung, jadi teteh itu meminta bantuan kepada saya sebagai leader team dalam mensukseskan teteh menjadi anggota dewan, karena saya sendiri pernah memiliki pengalaman dahulu menjadi tim dari kakak ipar saya yang nyalon juga (wawancara, 10 Januari 2020)

Een menungkapkan mengenai tim suksesnya. Berikut ungkapannya, "tim sukses tetap sama dan ada tambahan" (wawancara, 08 Januari 2020). Hal ini dibenarkan oleh Iwo selaku ketua tim sukses sebagai berikut, "Tim ini masih dengan yang sama seperti awal, tetapi ada beberapa tambahan karena periode pertama, kedua dan ketiga berbeda, suara juga harus ditambah jadi perlu adanya tenaga tambahan" (wawancara, 10 Januari 2020)

Iwo menjelaskan tentang awal-awal mengkampanyekan Een Rusmiyati sebagai anggota dewan, menurutnya kala itu perlu perjuangan keras yang dilakukan bersama timnya, berikut keterangan detail dari Iwo:

Awal-awal saya bersama tim memang susah sekali, saya membawa kopian contoh surat suara saya demokan dari rumah ke rumah dengan berjalan kaki, dengan keterbatasan dana pada saat itu sehingga untuk membeli air minum saja hanya satu tetapi diminum secara bergantian bersama tim (wawancara, 10 Januari 2020)

Hal tersebut tentu akan menjadi kenangan yang tak bisa dilupakan oleh Iwo beserta timnya, kerja keras yang dilakukannya memberikan hasil dengan terpilihnya Een Rusmiyati menjadi anggota dewan, Suniah (pemilih Een) menyatakan tentang sosok Een Rusmiyati sebagai berikut, "Ibu Een itu sosoknya baik, perhatian terhadap masyarakat kecil, dekat juga dengan masyarakat jadi ya sudah banyak yang tahu sih dari adikadiknya juga sama seperti itu" (wawancara, 23 Januari 2020). Pendapat lain dari Ida Rustini (pemilih Een) "Ya kalau melihat sosok ibu ya baik, suka membantu juga pada tetangga sekitar, bukan hanya ibunya saja tetapi juga keluarganya memang baik" (wawancara, 30 Januari 2020)

Een mengungkapkan tentang mekanisme kampanye yang dilakukannya. Berikut ungkapannya, "Ya saya berkampanye pada setiap titik-titik yang ada tim saya disitu, dengan bertemu langsung kepada masyarakat tentu lebih mendekatkan saya dan lebih banyak yang mengenal" (wawancara, 08 Januari 2020). Kehadiran Een dalam kampanye diharapkan menarik perhatian masyarakat, berikut penuturan dari Iwo, "Ya teteh juga turun secara fisik untuk berkampanye disamping memang ada juga yang hanya tim saja turun ke lapangan tetapi kehadiran teteh juga dibutuhkan untuk menarik perhatian dari masyarakat sekitar" (wawancara, 10 Januari 2020)

Hamah (pemilih Een) menerangkan tentang kampanye yang dilakukan oleh Een dan tim suksesnya "Pada saat kampanye Ibu Een hadir bersama tim mendatangi setiap rumah warga disini" (wawancara, 30 Januari 2020). Namun, berbeda dengan keterangan dari Hemaliyana Putri "Waktu itu sih hanya ada tim suksesnya saja, memberikan contoh cara untuk mencoblos Ibu Een itu seperti apa, hanya itu saja" (wawancara, 30 Januari 2020)

Iwo menekankan bahwa untuk menjadi seorang anggota dewan memang tidak mudah, tetapi harus dilakukan dengan berbagai cara agar dapat mencapai tujuannya "Untuk menjadi anggota dewan itu harus punya lumbung suara, harus punya target, harus punya jaringan, dan juga harus mau bekerja keras dari awal karena itu yang paling penting memupuk masyarakat sedari awal" (wawancara, 10 Januari 2020) 
Een menerangkan bahwa menjaga konstituen dapat dilakukan dengan sederhana, karena pada dasarnya kebutuhan masyarakat itu harus terpenuhi, harus memberikan perhatian termasuk juga dalam berbagi kepada masyarakat yang membutuhkan "Cara menjaganya dengan sering bersilaturahmi, saya juga sering mengajak untuk makan, memberikan THR ketika idul fitri lalu saya juga menyumbang qurban pada idul adha, intinya harus selalu berbagi kepada masyarakat" (wawancara, 08 Januari 2020)

Pendapat dari Iwo dalam menjaga konstituen Een Rusmiyati, berikut pernyataannya:

Rasa persaudaraan, rasa kekeluargaan yang harus terpupuk dari awal sehingga konstituen teteh itu tetap konsisten memilih teteh, kita kan setiap wilayah ada perwakilan untuk itu bila ada permasalahan apapun dapat segera melaporkan sehingga tidak ada yang tidak tertangani (wawancara, 10 Januari 2020)

Peran tim sukses sangat membantu ketika kampanye maupun setelah caleg tersebut menjadi anggota dewan, hal ini diakui oleh Een berikut pernyataannya, "Tenaga dari tim sukses sangat dibutuhkan karena tim bekerja dengan turun langsung ke masyarakat pada saat pemilu maupun sesudah jadi, setelah turun ke lapangan tim ini hasilnya akan dilaporkan kepada saya" (wawancara, 08 Januari 2020). Hal tersebut dibenarkan oleh Iwo. Berikut penuturan dari Iwo, "Tetap bekerja, masing-masing punya tugasnya dan tentu sesuai dengan wilayah yang telah ditetapkan, karena memang masyarakat tahunya kita sehingga banyak juga yang melapornya kepada kita" (wawancara, 10 Januari 2020)

Di dalam kampanye tentu masing-masing calon anggota legislatif memiliki hal yang berbeda dalam janji-janji kampanye yang disampaikannya. Menurut Fajar tidak ada janji kampanye yang disampaikan oleh Een, berikut perkataannya, "Saat kampanye beliau tidak banyak mengubar janji sih, tapi beliau mengatakan bahwa aspirasi apapun yang dikeluhkan akan diperjuangkan" (wawancara, 30 Januari 2020). Hal yang sama disampaikan oleh Suniah, berikut pernyataannya, "Ibu tuh gak banyak ngumbar janji, intinya beliau mengatakan kalau ada keluhan pasti beliau bantu itu saja sih" (wawancara, 23 Januari 2020)

Kedekatan tempat tinggal antara calon anggota legislatif dan pemilih dapat menjadi sumber suara, dimulai dari yang terdekat seperti tetangga sekitar rumah. Menurut Ida Rustini yang memilih Een karena kedekatan tempat tinggalnya, berikut penjelasannya, "Ya Ibu itu tetangga saya, masa saya pilih orang lain yang tidak dikenal" (wawancara, 30 Januari 2020). Lebih lanjut Ida juga mengajak Hemaliyana Putri untuk memilih Een. Berikut penuturan dari Putri "Saya diajak sama Ibu Ida untuk memilih Ibu Een, jadi ya saya ikut aja" (wawancara 30 Januari 2020)

Een menerangkan tentang dana kampanye pada pemilihan legislatif tahun 2009, 2014 dan 2019, berikut detail keterangan dari Een:

Pada awal saya mengikut pemilu tahun 2009 itu tidak memakai dana kampanye. Namun, dalam pemilihan berikutnya tahun 2014 dan 2019 semakin tinggi dana kampanye yang dikeluarkan tentu saya harus mencari dana itu, terus terang saya menggunakan dana pribadi saya untuk berkampanye (wawancara, 08 Januari 2020) Iwo selaku ketua tim sukses dari Een juga menjelaskan tentang dana kampanye: Awal memang tidak memakai dana kampanye karena masih tradisional dengan datang rumah ke rumah. Namun, semakin hari semakin kesini budget anggaran untuk 
sosialisasi, operasional dan lain sebagainya semakin tinggi karena untuk meningkatkan suara juga (wawancara, 10 Januari 2020)

Didalam perkembangan teknologi yang canggih, Een tidak menggunakan media sosial dalam berkampanye. Berikut detail pernyataannya, "Saya tidak menggunakan media sosial dalam berkampanye, lebih sering turun langsung saja, tetapi saya juga menggunakan media cetak untuk berkampanye seperti koran" (wawancara, 08 Januari 2020). Namun, Iwo memiliki alasan mengapa tidak menggunakan media sosial dalam berkampanye. Berikut alasan dari Iwo, "Ya kita lihat dahulu daerah pemilihan Ibu Een, banyak masyarakatnya yang tidak mengerti atau gagap teknologi sehingga kita sebagai tim dan juga Ibu Een tidak menggunakan media sosial dalam berkampanye" (wawancara, 10 Januari 2020)

Kampanye hitam tidak dilakukan oleh Een dalam berkampanye. Berikut ungkapannya, "Saya tidak menggunakan hal tersebut, itu bisa merugikan saya dan tentunya partai akan merugi, itu salah satu bentuk dari pencideraan demokrasi dan itu tidak fair" (wawancara, 08 Januari 2020). Hal yang sama juga ditekankan oleh Iwo. Berikut penekanan dari Iwo, "Kami tidak melakukan hal tersebut, kita berkampanye apa adanya saja, terutama yang tidak melawan aturan hukum didalam pemilihan legislatif" (wawancara, 10 Januari 2020)

Een juga menerangkan tentang kepentingan konstituennya. Berikut penjelasannya, "Kebutuhan mendesak harus dibantu, jika kiranya kebutuhan tersebut tidak terlalu dibutuhkan atau tidak bisa langsung dikerjakan, maka saya tampung terlebih dahulu" (wawancara, 08 Januari 2020)

Adanya tim sukses dari Een dapat membantu keluhan dari konstituennya, hal ini dirasakan oleh Suniah. Berikut pernyataan dari Suniah, "Pada saat itu anak saya tidak bisa diambil ijazahnya, tetapi ketika saya meminta pertolongan kepada Mas Iwo, Alhamdulillah ijazah anak saya bisa diambil" (wawancara, 30 Januari 2020). Adapun, hal lain yang disampaikan oleh Fajar berkaitan dengan akses publik. Berikut keterangan dari Fajar, "Saya mengusulkan pada saat reses Ibu Een untuk meminta perbaikan jalan, masjid dan jembatan. Kemudian Alhamdulillah sudah terwujud dan dapat digunakan bersama masyarakat yang lainnya juga" (wawancara, 30 Januari 2020)

Een mengungkapkan tentang banyaknya permintaan bantuan setelah menjadi anggota dewan. Berikut ungkapannya "Saya banyak diminta bantuan oleh masyarakat, berbagai bantuan seperti pemasangan listrik, sumur, rumah roboh sampai sekolah terkadang itu menggunakan dana pribadi saya sendiri" (wawancara, 08 Januari 2020)

Sebagai seorang anggota dewan perempuan, Een menyatakan bahwa harus berani dan bertanggung jawab ketika berada diparlemen. Berikut pernyatannya, "Sebagai seorang anggota dewan harus berani, harus bertanggung jawab dan harus mengajukan ke dinas terkait mengenai permasalahan masyarakat yang ada, karena kepentingan yang sudah dihimpun harus bisa diperjuangkan diparlemen" (wawancara, 08 Januari 2020)

Tidak ada program khusus yang dikeluarkan oleh Een, semua bergantung pada kebutuhan masyarakat masing-masing. Berikut pernyataan Een, "Untuk kaum ibu-ibu bisa senam, lalu untuk pemuda laki-lakinya bisa mengikuti futsal atau sepakbola, tergantung kebutuhan masyarakat saja karena mereka yang mengusulkan" (wawancara, 08 Januari 2020). Iwo juga menekankan mengenai prioritas yang harus memiliki manfaat bagi masyarakat banyak. Berikut penekanan dari Iwo, "Prioritas harus diutamakan 
dalam menentukan kepentingan, karena memilih dari banyak pilihan itu sulit tetapi harus melihat kebermanfaatan bagi masyarakat juga, intinya yang paling banyak manfaatnya yang didahulukan" (wawancara, 10 Januari 2020)

Een mengutarakan tentang reses yang dilakukannya. Berikut ungkapan dari Een, "Reses dilakukan setiap empat bulan sekali, masyarakat dikumpulkan lalu memilih permasalahan yang urgensi untuk dicarikan solusinya, masalah yang memang diprioritaskan atau kebutuhan masyarakat yang didahulukan" (wawancara, 08 Januari 2020). Lebih detail keterangan dari Iwo. Berikut pernyatannya, "Reses yang dilakukan meriah karena ada pesta dangdut, makanan, cemilan, yang datang banyak karena masing-masing wilayah diberi undangan untuk hadir didalam reses" (wawancara, 10 Januari 2020)

Iwo menyatakan tentang mobil yang dimilikinya untuk melayani masyarakat yang membutuhkan. Berikut pernyataan dari Iwo, "Kami punya mobil untuk masyarakat jadi kalau dibutuhkan bisa digunakan misal untuk menghantarkan orang ke rumah sakit, nikah atau apapun bisa menggunakan mobil tersebut" (wawancara, 10 Januari 2020). Hal tersebut dibenarkan oleh Hamah (pemilih Een). Berikut penuturannya, "Benar, mobil itu bisa digunakan oleh siapapun yang membutuhkan, kadang juga bisa untuk menjenguk orang sakit atau untuk rombongan besan yang nikahan" (wawancara, 30 Januari 2020)

Kebaikan seorang Een diungkapkan oleh Suniah sebagai berikut, "Ibu Een itu sering memberikan santunan kepada anak yatim piatu, kemudian juga kepada jandajanda yang ada disini dan orangtua yang tidak mampu, baik hati orangnya" (wawancara, 23 Januari 2020). Hal demikian juga ditegaskan oleh informan lain, Iwo menerangkan tentang keterpilihan Een selama tiga periode berturut-turut sebagai anggota dewan merupakan sebuah keberhasilan Een dalam merangkul konstituen dan timnya, berikut keterangan dari Iwo:

Ibu merepresentasikan semuanya, baik itu masyarakat daerah pemilihan kecamatan harjamukti dan juga kami sebagai tim yang selalu bekerja untuk melayani masyarakat, intinya selama ini Ibu dan kami selalu bisa bekerja sama dengan baik untuk membantu masyarakat (wawancara, 10 Januari 2020)

\section{Analisis Representasi dan Strategi Politik Een Rusmiyati}

Strategi keterpilihan petahana adalah cara, metode dan teknik yang digunakan calon petahana dalam mengikuti kontestasi pemilu melalui jabatan sebagai wakil rakyat guna terpilih kembali dengan mempertimbangkan aspek nilai-nilai inti audiens yang relevan. Penelitian ini menggunakan representasi politik dari Vieira dan Runciman, strategi politik dari Jagdish N. Sheth dan Gary L. Frazier. Berikut analisis representasi dan strategi politik Een Rusmiyati dalam keterpilihannya:

Tabel 1 Peta Analisis Representasi dan Strategi Politik

\begin{tabular}{|c|l|l|}
\hline Konsep & Dimensi & Een Rusmiyati \\
\hline $\begin{array}{c}\text { Representasi } \\
\text { Politik }\end{array}$ & Pictorial Representation & $\begin{array}{l}\text { Konstituen masyarakat umum, basis } \\
\text { konstituen jaringan keluarga. }\end{array}$ \\
\hline
\end{tabular}




\begin{tabular}{|c|c|c|}
\hline & $\begin{array}{l}\text { Theatrical } \\
\text { Representation }\end{array}$ & $\begin{array}{l}\text { - Hasil reses diusulkan ke dinas } \\
\text { terkait untuk diperjuangkan di } \\
\text { parlemen. } \\
\text { - Memberi bantuan dari dana } \\
\text { pribadi. }\end{array}$ \\
\hline & Juridical Representation & $\begin{array}{l}\text { Reses per } 4 \text { bulan (hadir secara } \\
\text { pribadi), kegiatan reses menggunakan } \\
\text { musik dangdut dan jamuan }\end{array}$ \\
\hline \multirow{4}{*}{ Strategi Politik } & Reinforcement Process & $\begin{array}{l}\text { - Memberi THR dan santunan } \\
\text { kepada anak yatim piatu, orang } \\
\text { tua tidak mampu, dan janda. } \\
\text { - Relasi dengan tim relawan jangka } \\
\text { panjang. } \\
\text { - Ketua tim relawan adik kandung }\end{array}$ \\
\hline & Rationalization Process & $\begin{array}{l}\text { - Mengunjungi konstituen. } \\
\text { - Menggunakan media cetak koran. }\end{array}$ \\
\hline & Inducement Process & $\begin{array}{l}\text { - Tidak mengumbar janji kampanye } \\
\text { - Menggelar simulasi pencoblosan }\end{array}$ \\
\hline & Confrontation Process & $\begin{array}{l}\text { - Menggunakan media cetak koran. } \\
\text { kampanye pertemuan tatap } \\
\text { muka. }\end{array}$ \\
\hline
\end{tabular}

Uraian di atas menjelaskan bagaimana fungsi representasi politik Een Rusmiyati dikelola bersama tim suksesnya, ia mampu membangun citra sosialnya sebagai orang baik yang hadir di tengah masyarakat. Een Rusmiyati dengan dibantu tim suksesnya mampu memecahkan masalah, pribadi maupun umum, yang dihadapi kontituennya. Modalitas ini yang selanjutnya menjadi keunggulan Een Rusmiyati sebagai calon anggota legislatif.

Lebih lanjut dapat dijelaskan melalui teori representasi politik dari Vieira dan Runciman, Pictorial representation (wakil menyerupai yang diwakili) dapat dijelaskan bahwa pemilih dari Een ialah beragam atau umum baik itu laki-laki maupun perempuan karena ia pribadi memulainya dengan memupuk masyarakat dari bawah, selain hal tersebut Een juga mengembangkan jaringan keluarganya yang berada pada dapil 2 Kota Cirebon dengan dukungan dari adiknya selaku ketua tim sukses Een agar pada saat pemilihan memilihnya, hal tersebut memberikan gambaran bahwa tidak selalu calon anggota legislatif perempuan dipilih juga oleh perempuan dan hal terpenting ialah Een dapat mengembangkan jaringan dari keluarga bersama dengan tim suksesnya.

Theatrical representation (wakil menafsirkan, berbicara, bertindak untuk yang diwakili) berdasarkan penuturan dari Fajar "saat ibu reses saya mengusulkan perbaikan jalan, masjid dan jembatan. Kemudian Alhamdulillah sudah terwujud dan dapat digunakan bersama masyarakat yang lainnya juga". Hal tersebut ditekankan oleh Een "saat reses masyarakat dikumpulkan lalu memilih permasalahan yang urgensi untuk dicarikan solusinya". Lebih jauh Een menerangkan "sebagai anggota dewan harus berani mengajukan ke dinas terkait mengenai permasalahan masyarakat yang ada, karena 
kepentingan yang sudah dihimpun harus bisa diperjuangkan di parlemen, terkadang itu menggunakan dana pribadi saya sendiri". Berdasarkan hal tersebut Een menafsirkan, berbicara, bertindak untuk yang diwakili, diluar hal yang berkaitan sebagai anggota legislatif ia adalah pribadi yang dikenal baik oleh konstituennya dan pengalaman tiga periode membuat Een mudah membangun komunikasi dengan dinas daerah/SKPD terkait.

Juridical representation (wakil bertindak dengan persetujuan yang diwakili), reses merupakan salah satu agenda yang dilaksanakan oleh Een untuk memecahkan sebuah permasalahan yang berada ditengah masyarakat lalu kemudian masalah tersebut ia bawa ke dalam parlemen, lebih lanjut diluar dari reses Een merupakan pribadi yang suka memberi kepada konstituennya dengan berbagai macam bantuan, terlebih beberapa konstituennya tak sungkan untuk meminta pertolongan langsung kepada Een, hal tersebut menggambarkan bahwa Een menampung aspirasi melalui reses yang kemudian ia perjuangkan ke dalam parlemen dan bukti tersebut telah disampaikan oleh salah satu konstituennya bernama Fajar, oleh karena itu ia mengatakan bahwa menjadi seorang anggota dewan legislatif terlebih perempuan maka harus berani, harus bertanggung jawab dan harus mengajukan ke dinas terkait mengenai permasalahan masyarakat yang ada.

Lebih lanjut dalam strategi politik, Reinforcement process (menjaga orang dalam sikap positif melalui memperkuat perilaku, memperkuat sikap atau memperkuat keduanya) dapat diterangkan bahwa hal ini dilakukan oleh Een dengan memberi santunan atau tunjangan hari raya bahkan lebih dari itu turut menyumbang dalam pembangunan rumah salah satu masyarakat atau konstituennya lebih dari itu tidak bisa dikatakan hadiah bahwa itu melebihi dari hadiah karena memang yang dibutuhkan lebih dari itu, lebih lanjut bahwa tidak ada program atau proyek yang diberikan kepada tim sukses karena memang tim ini dibuat untuk bekerja setiap harinya menangani banyak masalah yang ada di lingkungan masyarakat sehingga tidak ada proyek yang dapat diterima dari tim sukses ini selain karena memang adik kandung sendiri tetapi potensi itu tetap ada, hal ini tidak terlihat dari sejumlah penuturan konstituen atau masyarakat yang merasakannya, jelas disini bahwa konstituen diberikan kebutuhan yang cukup jika itu memang diperlukan bahkan harus mengeluarkan dana pribadi dari Een untuk bisa mengatasi permasalahan yang diterima atau diminta langsung dari masyarakat atau konstituen.

Rationalization process (menghasilkan perubahan sikap perilaku yang lebih konsisten) dapat dipahami bahwa yang dilakukan oleh tim sukses dari Een sudah jelas melakukan kunjungan dari rumah ke rumah pada awal periode pencalonan Een menjadikan bahwa masyarakat atau konstituen sebagai target untuk meraih suara dengan sebanyak-banyaknya karena pada saat itu masih awal jadi melakukannya dengan tradisional berlanjut juga menggunakan media cetak seperti koran agar dapat menarik perhatian masyarakat untuk memilih Een, tentu saja dengan datang dan berkunjung dari rumah ke rumah untuk memberikan keyakinan kepada masyarakat agar memilih Een hal tersebut dilakukan agar masyarakat tetap konsisten dalam mendukung hingga pencoblosan itu tiba.

Inducement process (mengubah perilaku orang dalam sikap negatif menjadi positif) hal ini dapat dijelaskan bahwa janji-janji pada saat kampanye tidak begitu 
dilakukan oleh Een karena berdasarkan penuturan dari konstituen yang bernama Fajar dan Suniah bahwa Een tidak banyak mengumbar janji agar dipilih sebagai seorang anggota dewan, rayuan janji kampanye tidak dilakukan oleh Een, selanjutnya memberikan arahan dukungan ketika kampanye hal ini tentu saja dilakukan oleh tim suksesnya karena dengan melakukan simulasi pencoblosan surat suara dari rumah ke rumah masyarakat tentu mengisyaratkan atau memberikan arahan untuk memilih Een, dari dua hal tersebut tentunya dapat dipastikan cara yang kedua digunakan untuk mengubah perilaku orang dalam sikap negatif menjadi positif karena dengan memberikan arahan dukungan melalui simulasi pencoblosan yang dilakukan akan mengubah masyarakat tersebut.

Confrontation process (mengubah perilaku sosial dalam opini publik dengan menggunakan basis kekuatannya untuk mengubah perilaku sosial secara massif) dalam hal ini dapat dikatakan bahwa media sosial dapat digunakan oleh calon anggota legislatif dalam mempengaruhi publik untuk memilih. Namun, Een beserta timnya tidak menggunakan media sosial dalam mempengaruhi publik untuk memilih dirinya dengan alasan bahwa masyarakat daerah pemilihan Een banyak yang tidak mengerti tentang media sosial sehingga hal tersebut tidak digunakan. Een berkampanye menggunakan media cetak seperti koran untuk menambah suaranya, karena memang penyebaran info yang lebih terjangkau untuk daerah pemilihan tersebut menggunakan koran, kemudian untuk kampanye hitam dan politik uang Een beserta tim tidak menggunakan hal tersebut untuk mempengaruhi publik dalam memilih akan tetapi dengan catatan bahwa biaya kampanye yang semakin tinggi tentu membutuhkan uang yang banyak akan tetapi uang tersebut digunakan untuk operasional selama massa kampanye berlangsung.

\section{Penutup}

Kemenangan hatrrict Een Rusmiyati menunjukkan bekerjanya hukum "reward and punishment" dalam pemilu, pemilih Een Rusmiyat memberi reward dengan kembali memilih Een Rusmiyati di Pemilu 2019 berdasar hubungan wakil-konstituen yang terus dirawat. Een Rusmiyati mampu merawat konstituennya dengan tetap hadir di tengah mereka melalui fungsi representasi politik. Saat pemilu, fungsi representasi politik menjadi keunggulan Een Rusmiyati untuk kembali terpilih. Tim sukses adalah aktor yang berperan penting dalam merawat hubungan wakil-konstituen. Penelitian ini menunjukkan ada hubungan jangka panjang antara Een Rusmiyati dengan tim suksesnya, hubungan ini terjaga oleh karena ketua tim sukses adalah adik laki-laki kandung.

Penelitian ini menunjukkan Een Rusmiyati dinilai konstituennya telah melakukan fungsi representasi yang bisa dijadikan strategi politik untuk keterpilihan berikutnya. Namun konstituen masih memaknai representasi sebagai "bantuan material" yang membutuhkan modal ekonomi besar, cara ini juga mengaburkan kampanye sebagai bentuk kontrak politik wakil-konstituen. Tekait hal itu, saran yang dapat diberikan ialah perlunya upaya terus menerus melakukan pendidikan politik kepada pemilih. Wakilwakil rakyat juga didorong menjual program kerja sebagai strategi pemenangan. 


\section{Ucapan Terima Kasih}

Terima kasih kepada seluruh informan yang telah memberikan waktu dan informasi selama penelitian lapangan berlangsung.

\section{Pendanaan}

Penulis tidak menerima bantuan pembiayaan untuk penelitian, kepenulisan (authorship), dan publikasi dari pihak manapun.

\section{Daftar Pustaka}

Adlin, A., \& Triawang, A. (2015). Strategi Komunikasi Politik Dedi Humadi dalam Pemilihan Umum Legislatif Anggota Dewan Perwakilan Rakyat Daerah Kabupaten Rokan Hilir Tahun 2014. Riau University.

Aswagati, S. (2019). Merawat Konstituen Politik: Studi Kasus Calon Legislatif Petahana Partai Demokrat Daerah Pemilihan I Jawa Tengah Periode Pemilihan Legislatif 2009 dan 2014. Universitas Diponegoro.

Ayu, I., Indriani, D., \& Azhar, M. A. (2019). Perempuan Petahana Pada Pemilu Serentak Tahun 2019 di Provinsi Bali, 1-8.

Azis, A. (2013). Dilema Keterwakilan Perempuan dalam Parlemen: Suatu Pendekatan Hukum yang Perspektif Gender. Rangkang Education.

Ban, P., Llaudet, E., \& Snyder Jr, J. M. (2016). Challenger Quality and The Incumbency Advantage. Legislative Studies Quarterly, 41(1), 153-179.

Creswell, J. (2014). Penelitian Kualitatif \& Desain Riset: Memilih di Antara Lima Pendekatan (A. Lazuardi, Trans.). Yogyakarta: Pustaka Pelajar.(Original Work Published 1998).

Firmanzah, P. D. (2008). Marketing Politik. Antara Pemahaman Dn Realitas.

Nikmah, N. (2015). Kandidat Petahana DPRD Kota Surabaya Pada Pemilu Legislatif 2014 (Studi Deskriptif Caleg Terpilih Melalui Partai Kebangkitan Bangsa). Universitas Airlangga.

Ning, R. D., Erviantono, T., \& Azhar, M. A. (2016). Strategi Incumbent Parpol Mempertahankan Suara Pasca Pindah Partai pada Pemilu Legislatif Kota Denpasar Tahun 2014. Politika Udayana, 1(1).

Osuagwu, L. (2008). Political Marketing: Conceptualisation, Dimensions and Research Agenda. Marketing Intelligence \& Planning.

Saward, M. (2006). The Representative Claim. Contemporary Political Theory, 5(3), 297318.

Setyo, B. (2016). Model Kampanye Politik Berbasis Silaturahim Bagi Calon Anggota Dewan Incumbent dalam Pemilu Legislatif 2014. ETTISAL: Journal of Communication, 1(2), 188-207.

Sheth, J. N., \& Frazier, G. L. (1982). A Model of Strategy Mix Choice for Planned Social Change. Journal of Marketing, 46(1), 15-26.

Sugiyono. (2013). Metode Penelitian Pendidikan Kuantitatif, Kualitatif dan R\&D. Bandung: Alfabeta.

Veronika. (2013). Pemasaran Politik Legislatif Petahana Dalam Memenangkan Pemilu Anggota Dprd Kota Kupang Provinsi Nusa Tenggara Timur Tahun 2009 (Kajian 
Strategi Politik Dan Bauran Produk Politik). Politika: Jurnal Ilmu Politik, 3(2), 5-14. Vieira, M. B., \& Runciman, D. (2008). Representation. Polity.

\section{Daftar Narasumber}

Een Rusmiyati, Anggota Dewan Perwakilan Rakyat Daerah Kota Cirebon, wawancara pada tanggal 08 Januari 2020, pukul 10.00 WIB.

Iwo, Ketua Tim Sukses Een Rusmiyati, wawancara pada tanggal 10 Januari 2020, pukul 09.00 WIB.

Suniah, Konstituen Een Rusmiyati, wawancara pada tanggal 23 Januari 2020, pukul 10.00 WIB.

Fajar, Konstituen Een Rusmiyati, wawancara pada tanggal 30 Januari 2020, pukul 11.00 WIB.

Hamah, Konstituen Een Rusmiyati, wawancara pada tanggal 30 Januari 2020, pukul 11.15 WIB.

Ida Rustini, Konstituen Een Rusmiyati, wawancara pada tanggal 30 Januari 2020, pukul 11.30 WIB.

\section{Tentang Penulis}

Akhmad Muzadi adalah mahasiswa Magister IImu Politik Fakultas IImu Sosial dan IImu Politik Universitas Diponegoro.

Fitriyah adalah dosen Departemen Politik dan Pemerintahan, Fakultas IImu Sosial dan IImu Politik, Universitas Diponegoro. Memiliki area kajian seputar politik gender dan partai politik. 